\title{
KANONICZNA KONCEPCJA CZYNNOŚCI PRAWNEJ WPROWADZENIE DLA PRAWNIKÓW ŚWIECKICH
}

\begin{abstract}
Abstrakt. Autor przedstawia ogólnie koncepcję kanoniczną czynności prawnej (por. kan. 124-127 CIC). Wskazuje na jej teologiczny i antropologiczny fundament (osoba i actus humanus) oraz korzenie w europejskiej tradycji prawnej. Według autora czynność kanonicznoprawna to taki czyn ludzki (actus humanus), który jest czynnością konwencjonalną (aktem formalnym) oraz wywołuje określone i chciane skutki prawne. Koncepcją kanonicznej czynności prawnej rządzą trzy zasady: personalizmu (podkreślenie osobowego charakteru), uniwersalizmu (szeroki zakres zastosowania pojęcia, również na czynności o charakterze publicznym) i trwałości (zachowania czynności prawnej).
\end{abstract}

Słowa kluczowe: czynność prawna, prawo kanoniczne, kan. 124-127 CIC, kan. 931-934 CCEO.

\section{OSOBA I CZYN - PODSTAWY TEOLOGICZNE I ANTROPOLOGICZNE}

Porządek kanoniczny w sposób konieczny musi odnosić się do Boga i do człowieka jako osoby. „Bóg bowiem tak umiłował świat, że Syna swego Jednorodzonego dał" (J 3, 16). Człowiek-osoba jest przecież dzieckiem Bożym (por. J 1, $12 ; 11,52)$.

Te założenia teologiczne Sobór Watykański II oddaje też językim personalistycznym. Wyraża się bardzo jasno: „Osoba ludzka jest i powinna być zasadą, podmiotem i celem wszystkich instytucji społecznych"1 (Gaudium et spes, n. 25, 1, cytując św. Tomasza z Akwinu). Człowiek bowiem determinuje swoje czyny, a osoba wyraża się poprzez czyn, jak uważał Karol Wojtyła (Wojtyła 1969, $73)^{2}$. Fenomenologicznie rzecz ujmując, osoba wyraża się w doświadczeniu zawartym w ,ja działam” (tamże, 61). Następuje „dynamiczne sprzęgnięcie czynu z osobą" (tamże, 67), ,przeżycie »jestem sprawcą«" (tamże, 68). Zgodnie ze

* Uniwersytet Papieski Jana Pawła II w Krakowie, Wydział Prawa Kanonicznego, Katedra Kanonicznego Prawa Karnego, piotr.skonieczny@upjp2.edu.pl.

${ }^{1}$ Sobór Watykański II 1967, 561: "Etenim principium, subiectum et finis omnium institutorum socialium est et esse debet humana persona".

${ }^{2}$,Sprawczość ludzka zdaje się być jakąś twórczością. Jest to ta twórczość, dla której pierwszym tworzywem jest sam człowiek. Człowiek przez działanie kształtuje przede wszystkim siebie". 
starożytną paremią: hominum causa omne ius constitutum est (Digesta I, 5, 2) fundamentem prawa w ogóle, a w szczególności prawa kanonicznego jest osoba (De Paolis, D’Auria 2008, 330)․ Tę dominację osoby w porządku kanonicznym można nazwać zasadą personalizmu.

Nic dziwnego więc, że takie właśnie podstawy teologiczne i antropologiczne musiały kształtować również instytucję czynności prawnej (actus iuridicus) W prawie kanonicznym (De Paolis 2002, 32) ${ }^{4}$. Czynność prawna w porządku kanonicznym okazuje się takim działaniem człowieka (actus hominis), które jest też ludzkie (actus humanus) (Wojtyła 1969, 68). Czynność prawna więc (actus iuridicus) musi być czynem ludzkim (actus humanus). To zaś oznacza, że owa czynność ma być dokonana świadomie i dobrowolnie. Skutek prawny przecież musi być przypisany wolnej woli osoby, która dokonuje danej czynności (De Paolis, D’Auria 2008, 330).

Tak rozumiana zasada personalizacji rządzi w całym porządku kanonicznym, który przecież osadzony jest na rzeczywistości teologicznej. Skoro osoba (także w rozumieniu Osób Boskich Trójcy Przenajświętszej) znajduje się w centrum Kościoła, to oczywiste jest, że również osoba będzie tym elementem, które organizuje porządek kanoniczny, w tym instytucję czynności prawnej.

Jak zatem widać już na wstępie, porządek kanoniczny wyraźnie różni się w punkcie wyjścia od systemu prawa świeckiego. Podstawy teologiczne i antropologiczne wpływają bowiem znacząco - i to od wewnątrz (sic!) (Baura 2013, 166) - na kształt poszczególnych instytycji kanonicznoprawnych. Z tego względu prawo kanoniczne jako complexus legum, pewien system prawny (tamże, 159), lepiej nazywać porzadkiem kanonicznym (ordinamento canonico) aniżeli systemem. Nie chodzi zatem o system prawa w rozumieniu pozytywizmu prawnego - samowystarczalny, w którym teologia i prawo Boże nie odgrywają żadnej roli i nie są jego częściami składowymi (tamże, 162-164). Nie tylko, że teologia i prawo Boże są częściami składowymi, ale nawet podstawa i sama treścia tego porządku prawnego. Porządek kanoniczny jest strukturą prawną Kościoła (Lombardía 1985, 7-8, 15-19; Hervada 1989, 157-268; Baura 2013, 161). Stosunki prawne w tym porządku organizują lud Boży, czyli Kościół, i nie mają charakteru statycznego, lecz dynamiczny.

${ }^{3},[\ldots]$ il fondamento del diritto è la persona".

${ }^{4}$ Niekiedy w niniejszym artykule - dla podkreślenia, że chodzi o czynność prawną w porządku kanonicznym - mowa jest o czynności „kanonicznoprawnej”.

${ }^{5} \mathrm{~W}$ języku łacińskim (i włoskim) czynność i czyn ludzki wyrażany jest tym samym słowem - actus (atto). 


\section{CZYNNOŚĆ PRAWNA JAKO STOSUNEK KANONICZNOPRAWNY}

\subsection{Elementy stosunku kanonicznoprawnego}

Z punktu widzenia teorii prawa interakcje między osobami można nazwać stosunkami prawnymi, na gruncie prawa kanonicznego - stosunkami kanonicznoprawnymi. W stosunkach kanonicznoprawnych można wyróżnić następujące elementy (Radwański 1993, 137):

a) podmioty, czyli osoby w znaczeniu prawnym,

b) przedmioty lub treść,

c) zdarzenia prawne, czyli interakcje.

Stosunki kanonicznoprawne są wyznaczone normami kanonicznoprawnymi. Normy kanonicznoprawne to reguły powinnego postępowania wiernego, wywiedzione z przepisów kanonicznych ${ }^{6}$. Normy te regulują owe stosunki. Porządek kanoniczny zatem jest dla nich punktem odniesienia i dlatego nazywają się one kanonicznoprawnymi.

\subsection{Analiza poszczególnych elementów stosunku kanonicznoprawnego}

Ad a) Podmiotami stosunków kanonicznoprawnych są osoby fizyczne i prawne (por. kan. 96-123 CIC; 909-930 CCEO)7, ale nie osoby świętych czy Osoby Trójcy Przenajświętszej. Te ostatnie bowiem nie są podmiotami prawa kanonicznego, a jedynie podmiotami w znaczeniu teologicznym $\mathrm{i}$ - ewentualnie - przedmiotem regulacji kanonicznej.

Ad b) Treścią stosunków kanonicznoprawnych są zwykle dobra duchowe (np. sakramenty) lub inne dobra związane z tymi dobrami duchowymi (np. ofiary mszalne czy dobra doczesne Kościoła).

Ad c) Osoba uzyskuje dobra duchowe lub inne dobra z nimi związane poprzez zdarzenia prawne bądź kanonicznoprawne. Są to takie fakty czy okoliczności, z którymi związane są pewne skutki kanonicznoprawne (Radwański 1993, 137). To dopiero - przykładowo - wymiana zgody małżeńskiej (zdarzenie kanonicznoprawne) między ochrzczonymi małżonkami (osobami) powoduje, że między nimi zaistniał sakrament małżeństwa (treść czy przedmiot stosunku kanonicznoprawnego). To zdarzenie kanonicznoprawne wpływa na pozycję kanoniczną osoby, która staje się małżonkiem, a przez to nabywa pewne prawa i obowiązki w porządku kanonicznym.

${ }^{6}$ Tak właśnie jest w tym kręgu kanonistyki, który rozwija się w Europie pod wpływem nauki prawa świeckiego rodziny germańskiej, ale już nie romańskiej - zob. Sobański 1979, 273, 275; 1992, 147; 2001, 73; Aymans, Mörsdorf 1991, 2-3. Podobnie w literaturze doktryny polskiej, zob. Ziembiński 1992b, 188-193; Zieliński 2002, 47-48, 72-74, 103-131, 240-251, 269.

${ }^{7}$ Skróty CIC i CCEO oznaczają odpowiednio: Codex Iuris Canonici, czyli Kodeks Prawa Kanonicznego (zbiór prawa kanonicznego łacińskiego) oraz Codex Canonum Ecclesiarum Orientalium, tj. Kodeks Kanonów Kościołów Wschodnich (zbiór prawa wschodniego). Por. Codex Iuris Canonici... 1984; Codex Canonum Ecclesiarum Orientalium ... 1990. 


\subsection{Typy zdarzeń kanonicznoprawnych}

W życiu są zdarzenia czy fakty, do których dochodzi niezależnie od wolnej woli ludzkiej. Są to tzw. zdarzenia prawne sensu largo (eventus naturae) ${ }^{8}$. Zwykle to zdarzenia naturalne, które powodują skutki prawne, jak np. narodziny, śmierć, upływ czasu (np. ukończenie 18. roku życia), zmiana miejsca zamieszkania, trzęsienie ziemi czy inne kataklizmy 9 .

Od zdarzeń prawnych sensu largo odróżnia się wspomniane już czyny człowieka (actus hominis), które tym różnią się od owych zdarzeń, że są dokonywane z wolną wolą ludzką. Wśród tych czynów ludzkich należy odróżnić takie, które: a) nie wywołują skutków prawnych oraz b) takie, które je wywołują (zdarzenia prawne sensu stricto).

Ad a) Do pierwszej kategorii czynów ludzkich, tj. dokonywanych dobrowolnie przez osobę, ale niewywołujących żadnych skutków prawnych, można zaliczyć większość środków zbawienia w prawie kanonicznym, jak np. przyjmowanie komunii św. (por. kan. 918 CIC; 713 § 1 CCEO), wysłuchiwanie homilii (por. kan. 767 CIC; 614 CCEO), uczestnictwo w katechezie (por. kan. 773-780, 788-789 CIC; 617-624, 587 CCEO) (García Martín 2015, 493). Wszystkie te czyny są dokonywane $\mathrm{z}$ wolną wolą, świadomie, a zatem są czynami ludzkimi (actus humanus).

Ad b) W drugiej kategorii czynów ludzkich, które wywołują skutki prawne (zdarzenia prawne sensu stricto), należy wyróżnić dwie podkategorie.

Po pierwsze, są to czyny, których skutki prawne były zamierzone przez człowieka, np. przyjęcie chrztu. Są to tzw. czynności prawne (actus iuridicus) ${ }^{10}$. Te czynności prawne zwane są $\mathrm{w}$ doktrynie prawa cywilnego czynnościami konwencjonalnymi (Ziembiński 1992a, 78-79). Są to bowiem takie czynności, które dopiero norma prawna konstruuje, wyznaczając przesłanki jej dokonania przez określone działanie człowieka (Radwański 1993, 139), przykładowo: zawarcie małżeństwa, wydanie dekretu (aktu administracyjnego w prawie kanonicznym - por. kan. 48 CIC; $1510 \S 2$ n. 1 CCEO) czy wyroku, zawarcie umowy (Radwański 1993, 139) ${ }^{11}$.

${ }^{8}$ Tradycyjnie w starszej doktrynie rozpoznawano te eventus naturae (obecnie $\mathrm{w}$ doktrynie włoskojęzycznej nazywa się je eventi giuridici) jako facta juridica inovlontaria, zob. Michiels 1955 , 569. Inaczej - tylko jako fatto giuridico - fakt prawny, por. García Martín 2015, 493. Wszystkie inne facta juridica są voluntaria, por. Michiels 1955, 571. Podział ów zasadzał się na klasycznej teologii moralnej i dotyczył traktatu o czynach ludzkich, por. Romani 1938, 101. Prezentowane poglądy odnośnie do czynności prawnej jako zdarzenia kanonicznoprawnego są zatem osadzone na klasycznej doktrynie kanonistycznej, ale jest to własny pogląd autora.

${ }^{9}$ Także znane z prawa rzymskiego namulenie rzeki, które może spowodować nabycie prawa podmiotowego w postaci własności ziemi, zob. De Paolis, D’Auria 2008, 329 (przyp. 2).

${ }^{10} \mathrm{~W}$ literaturze włoskojęzycznej są one nazywane atti giuridici.

${ }^{11}$ Dla ścisłości w tej podkategorii należy też wskazać działania prawne, które są zbliżone do czynności prawnych, ale nimi nie są, jak np. oświadczenia wiedzy lub przejawy uczuć. 
Po drugie, mogą to być czyny, których skutki nie były chciane przez człowieka, np. takie zachowanie się, które wywołało szkodę (delikty w prawie cywilnym). Są to inne zdarzenia prawne, zwane też faktami prawnymi ${ }^{12}$. Do tej kategorii można również zaliczyć takie zdarzenia prawne, które polegają na niewykonywaniu uprawnień w określonym czasie, co może spowodować przedawnienie (kanoniczne) (Radwański 1993, 139) ${ }^{13}$.

Schematycznie zdarzenia kanonicznoprawne można przedstawić następująco (rys. 1).

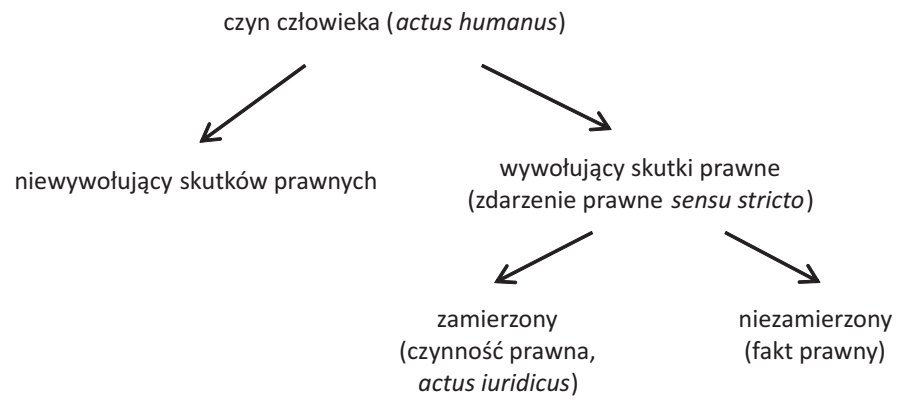

Rysunek 1. Zdarzenia kanonicznoprawne

Źródło: opracowanie własne.

Podsumowując, ujęcie czynności prawnej jako stosunku prawnego w kanonistyce nie odbiega od tego pojęcia w nauce prawa świeckiego.

\section{POJECIE KANONISTYCZNE CZYNNOŚCI PRAWNEJ}

\subsection{Definicja doktrynalna}

Kodeksy prawa kanonicznego łaciński i wschodni zawierają jednostki redakcyjne (tytuł VII księgi I CIC, czyli kan. 124-128 CIC, i odpowiednio rozdział II w tytule XIX CCEO, kan. 931-935 CCEO $^{14}$ ), zatytułowane De actibus iuridicis („Czynności prawne” ${ }^{15}$ ). Co ciekawe, ustawodawca kościelny zdecydował się na

${ }^{12}$ Chodzi o włoskie fatto giuridico, operazione; por. De Paolis, D’Auria 2008, 329.

${ }_{13}^{13}$ Jakkolwiek można też tego typu upływ czasu uznać za zdarzenie prawne sensu largo.

${ }^{14}$ Ta jednostka redakcyjna jest zupełnie nowa w prawie kanonicznym. Została stworzona z trzech kanonów kodeksu z 1917 (dalej w skrócie: CIC/17), ale w zupełnie nowym porządku systematycznym (kan. $103 \S 1$ i 2, 104 oraz 105 CIC/17). Natomiast dwa kanony są zupełnie nowe (kan. 124 i 128 CIC). Ewolucja przepisów nastąpiła w trakcie prac kodyfikacyjnych, zob. Peters 2005, 84-89; Di Carlo 2002, 13-19.

${ }^{15} \mathrm{~W}$ oficjalnym thumaczeniu na język polski De actibus iuridicis przetłumaczono jako „Akty prawne”. Pojęcie ,akt prawny” jest starszym terminem w polskim języku prawniczym, który jednak 
wyraźne nawiązanie do tradycji prawnej kontynentalnej ${ }^{16}$, świadomie odrzucając znane w Europie negotium juridicum ${ }^{17}$, o czym dalej (zob. pkt 3.3.2). Jednak kodeksy nie zawierają definicji legalnej czynności prawnej (Molano 2011, 146; De Paolis, D'Auria 2008, 331), podobnie zresztą jak np. prawo cywilne polskie czy niemieckie (Radwański 1993, 33).

Doktryna kanonistyczna musiała zatem wypracować definicję czynności prawnej w porządku kanonicznym. W kanonistyce znanych jest wiele prób ujęcia terminu. Można wskazać na dwie grupy zdefiniowania czynności kanonicznoprawnej (De Paolis 2002, 33). Pierwsza, która skupia się wokół definicji Gommara Michielsa (1890-1965), wskazuje na element antropologiczno-filozoficzny, typowy dla prawa kanonicznego (actus humanus) (Michiels 1955, 572) ${ }^{18}$. Druga grupa podąża za definicją zaproponowaną przez Olisa Robledę (1909-1980) i adoptuje pojęcie pandektowe na grunt prawa kanonicznego ${ }^{19}$, podkreślając wszakże centralne znaczenie aktu woli ludzkiej ${ }^{20}$.

Jak zatem widać, przy definiowaniu czynności kanonicznoprawnej niezbędne jest wzięcie pod uwagę całej tradycji kanonicznej, tj. fundamentów teologii

wyszedł już z użycia, zob. Radwański 2008, 38, nb. 102. Dlatego należy postulować zmianę obecnego tłumaczenia na „czynność prawną”. Właśnie w ten sposób ujmuje to Sobański 2003, 201; Codex Iuris Canonici... Komentarz 2011, 146.

${ }^{16}$ Nie zna tego pojęcia krąg kultury prawnej anglosaskiej, zob. Hughes 1980: 396-401, cyt. za: Pree 1998, Einführung vor 124/3, nb. 2.

17 Zatem odrzucając niemieckie Rechtsgeschäft, hiszpańskie negocio jurídico czy włoskie negozio giuridico, a przyjmując francuskie acte juridique, por. Thériault 2004, 796.

18 „Actus humanus socialis legitime positus et declaratus, cui a lege ideo et eatenus effectus juridicus determinatus agnoscitur, quia et quatenus effectus ille ab agente intenditur". Por. Fornés 1985: 71-73; García Martín 2015, 501; Pree 1998, Einführung vor 124/5-6, nb. 3; Thériault 2004, 797; Dzierżon 2000: 10-11; 2002, 26-28.

${ }^{19}$ Chodzi o definicję Bernharda Windscheida (1817-1892): „Rechtsgeschäft ist die auf die Enstehung, den Untergang oder die Veränderung von Rechten gerichtete Privatwillenserklärung", zob. Windscheid 1879, 176, § 69. Por. De Paolis 2002, 25, 36.

${ }^{20}$ Por. Robleda 1962: 419:, ,[...] pro actu iuridico intelligimus voluntatis actum externae manifestatum quo certus effectus iuridicus intenditur"; Robleda 1964, 7:, ,[...] es un acto de la volundad, externo, dirigido a producir determinados efectos jurídicos". Najpełniej tę doktrynę rozwiną inny profesor Uniwersytetu Gregorianum w Rzymie, por. Urrutia 1994, 201-202, nb. 663-667: „De façon générique on peut dire que l'»acte juridique« est l'acte personnel (d'une personne physique comme d'une personne juridique) qui modifie les rapports dans la communauté". Stąd czynność prawna jest aktem woli (por. tamże, nb. 664), skierowanym na wywołanie skutków prawnych, czyli na zmiany praw we wspólnocie (zob. tamże, nb. 665), uznanych przez ustawę (por. tamże, nb. 666). W literaturze włoskiej por. De Paolis 2002, 38-41; 1995, 405; De Paolis, D’Auria 2008, 332; Chiappetta 2011, 156, nb. 856-857; Pinto 2001, 76; Petrizzelli 2006, 28, cyt. za: García Martín 2015, 502, przyp. 31. Podobnie w literaturze hiszpańskiej, zob. Gangoiti 1993, 79; Vela Sanchez 1993, 66; Cortés Diéguez 2014, 91. Z literatury niemieckiej zob. Aymans, Mörsdorf 1991, 331. W literaturze polskiej zob. Pawluk 1990, 264; Sobański 2003, 202: „[...] czynność prawna to świadome działanie podjęte dla osiągnięcia zamierzonych skutków prawnych. Węzłowym, konstytutywnym elementem czynności prawnej jest wola (jako fakt wewnętrzny, subiektywny) i jej oświadczenie (jako fakt zewnętrzny, obiektywny)". W literaturze anglosaskiej zob. Wijlens 2000, 177. 
moralnej wraz z antropologią chrześcijańską. Z drugiej zaś strony nie można pominąć europejskiej tradycji prawnej. Stąd wydaje się, że na gruncie prawa kanonicznego czynność prawna (actus iuridicus) jest:

a) takim czynem ludzkim (actus humanus),

b) który jest czynnością konwencjonalną (aktem formalnym) i

c) który wywołuje określone i chciane skutki prawne.

W ten sposób określona czynność kanonicznoprawna z jednej strony jest mocno osadzona w tradycji kanonicznej, a zwłaszcza w teologii moralnej, poprzez podkreślenie za Michielsem, że chodzi o czyn ludzki jako zdarzenie prawne (por. pkt a). Poza tym nie jest jej obcy dorobek europejskiej tradycji prawnej, bo przecież chodzi o akt formalny wywołujący skutki prawne (por. pkt b i c), co z kolei nawiązuje do koncepcji Robledy.

Taka właśnie koncepcja stoi u podstaw kan. 124 CIC (kan. 931 CCEO), określającego ogólne przesłanki i domniemanie ważności czynności prawnej. Kanon ten stanowi $\mathrm{i}^{21}$ :

\begin{tabular}{|c|c|}
\hline $\begin{array}{l}\text { Can. } 124 \text { [can. } 931 \mathrm{CCEO} \text { ]: } \\
\S 1 . \text { Ad validitatem actus iuridici requiritur ut } \\
\text { a persona habili [CCEO: + et competenti] sit } \\
\text { positus, atque in eodem adsint [CCEO: assint] } \\
\text { quae actum ipsum essentialiter constituunt, } \\
\text { necnon sollemnia et requisita iure ad validitatem } \\
\text { actus imposita. }\end{array}$ & $\begin{array}{l}\text { Kan. } 124 \text { [kan. } 931 \text { CCEO]: } \\
\text { § 1. Do ważności czynności prawnej wyma- } \\
\text { ga się, by była dokonana przez osobę zdolną } \\
\text { [CCEO: + i (z zachowaniem) właściwości] oraz } \\
\text { by były zachowane te elementy, które tworzą } \\
\text { w sposób istotny samą czynność, oraz formalno- } \\
\text { ści i wymogi przewidziane prawem do ważności } \\
\text { czynności. }\end{array}$ \\
\hline $\begin{array}{l}\S 2 . \text { Actus iuridicus quoad [CCEO: circa] sua } \\
\text { elementa externa rite [CCEO: ad normam iuris] } \\
\text { positus praesumitur validus. }\end{array}$ & $\begin{array}{l}\text { § } 2 \text {. Domniemywa się ważność czynności praw- } \\
\text { nej należycie dokonanej w jej elementach ze- } \\
\text { wnętrznych. }\end{array}$ \\
\hline
\end{tabular}

\subsection{Analiza poszczególnych elementów definicji czynności prawnej}

\subsubsection{Czyn ludzki (actus humanus)}

Skoro czynność kanonicznoprawna jest zawsze czynem ludzkim (actus humanus), to istotą takiej czynności prawnej jest wola wewnętrzna człowieka (Michiels 1955,576$)^{22}$. Czynność prawna w prawie kanonicznym może być tylko czynnością dobrowolną, gdyż inaczej nie jest czynnością ludzką. Zgodnie z teologią moralną (św. Tomasz z Akwinu) czynność jest tylko wtedy ludzka (jest

${ }^{21}$ Tłumaczenie własne autora. W nawiasach kwadratowych wskazano różnice w tekście CCEO w stosunku do tekstu (łacińskiego) CIC; znak + wprowadza wyrażenie nowe w CCEO wobec CIC, a kursywa w $\S 2$ CIC - wyraz zastąpiony przez całe wyrażenie w CCEO.

${ }^{22}$ „Voluntatis actum debite positum”. 
czynnością człowieka), kiedy człowiek rzeczywiście nad nią panuje (jest jej panem - dominus) $)^{23}$. Taką czynność charakteryzują dwie cechy - zgodnie z zasadą nil volitum, nisi praecognitum (nic nie jest chciane, jeśli wcześniej nie zostało poznane) (tamże, 586):

a) poznanie (cognitio),

b) wolna wola (volitio, voluntas libera).

Ad a) Człowiek zwraca uwagę na przedmiot swego chcenia (woli). Musi poznać coś, by tego czegoś chcieć. Stąd najpierw musi zadziałać poznanie, by mogła zechcieć wola. To rozróżnienie jest szczególnie istotne w instytucji błędu (por. kan. 126 CIC; 933 CCEO) (tamże, 586).

Ad b) Chcenie (volitio) jest wewnętrznym aktem woli (actus voluntatis internus), rzeczywistym, pozytywnym i wolnym człowieka odnośnie do tego, co poznaje. Czynność prawna musi zatem być chciana (volitus), aby była skuteczna (tamże, 586-587). Brak dobrowolności lub jej ograniczenie wpływa na ważność czynności prawnej i stąd instytucje przymusu czy bojaźni (por. kan. 125 CIC; 932 CCEO). Co charakterystyczne dla prawa kanonicznego, akt woli powinien być zawsze pozytywny, nawet jeśli chodzi o wykluczenie swoją wolą pewnego elementu. Ma to swoje znaczenie w kanonicznym prawie małżeńskim (por. kan. $1101 \S 2$ CIC) (tamże, 587).

Jak zatem widać, przesłanka actus humanus wyraża samą istotę czynności kanonicznoprawnej. Jej odpowiednikiem w powołanym wyżej kan. $124 \S 1$ CIC (kan. $931 \S 1$ CCEO) są istotne elementy czynności prawnej, które ją konstytuują (quae actum ipsum essentialiter constituunt), tj. takie, bez których nie może dojść do dokonania czynności prawnej (por. kan. 86 CIC). Ponadto na cechę tę składa się zdolność osoby do dokonania danej, konkretnej czynności prawnej (persona habilis, w prawie wschodnim - także competens), czyli specyficzna zdolność do czynności prawnej, a nie ogólna zdolność do czynności prawnych (tamże, 578; García Martín 2015, 508-509).

Należy zwrócić uwagę, że prawo kanoniczne nie poprzestaje na oświadczeniu woli (jak większość ustawodawstw cywilnych świeckich, w tym polskie), lecz czynność kanonicznoprawna wymaga aktu woli wewnętrznej, o czym dalej przy zasadzie personalizmu (zob. pkt 3.3.1.2). W każdym razie nie można utożsamiać czynności kanonicznoprawnej z samym aktem woli, podobnie jak w doktrynie polskiego prawa cywilnego nie utożsamia się oświadczenia woli z czynnością prawną (Radwański 2008, 33-35).

${ }^{23}$ Thomas Aquinas 1888, pars I-II, quaestio 1, articulus 1, corpus: „Unde illae solae actiones vocantur proprie humanae, quarum homo est dominus. Est autem homo dominus suorum actuum per rationem et voluntatem, unde et liberum arbitrium esse dicitur facultas voluntatis et rationis. Illae ergo actiones proprie humanae dicuntur, quae ex voluntate deliberata procedunt". 


\subsubsection{Czynność konwencjonalna}

Wolę ma wyrażać czynność konwencjonalna. Czynność konwencjonalna oznacza, że to dopiero norma kanonicznoprawna nadaje pewnej konwencji (znakom, słowom) określone znaczenie.

$\mathrm{W}$ prawie kanonicznym - podobnie jak w polskim prawie cywilnym (por. art. 60 k.c.) - obowiązuje zasada swobody formy. Mimo to dla porządku kanonicznego ma znaczenie rozróżnienie czynności o przepisanej formie (formalne, actus formales seu sollemnes) i o formie dowolnej (actus non formales seu non sollemnes) (Michiels 1955, 591; Baura 2013, 97). Do czynności formalnych zaliczają się takie, które domagają się zachowania pewnych formalności przewidzianych przez normy kanonicznoprawne (np. w ustawie kościelnej - kan. 7 i 8 CIC; 1488 i 1489 CCEO; w małżeństwie odnośnie do formy kanonicznej - kan. 1108 CIC; 828 CCEO). Z kolei wszystkie pozostałe są czynnościami o formie dowolnej. Te ostatnie są niekiedy zwane, niezbyt ściśle, czynnościami „nieformalnymi”. Nawet bowiem jeśli czynność prawna jest o dowolnej formie, to jednak zawsze ma ona pewną formę, gdyż każda czynność konwencjonalna, jaką jest czynność prawna, ma jakąś formę.

W przepisie kan. $124 \S 1$ CIC (kan. 931 § CCEO) cechę tę wyrażają formalności (sollemnia) i wymogi prawne (requisita). Formalności oraz inne wymogi prawne nie zawsze są żądane pod rygorem nieważności czynności prawnej, ale tylko wtedy, kiedy prawo tak wyraźnie stanowi (por. kan. 10 CIC; 1495 CCEO) (De Paolis, D'Auria 2008, 337). Taka regulacja znajduje swoje uzasadnienie w tym, że forma i inne wymogi prawne nie należą do istoty czynności kanonicznoprawnej.

\subsubsection{Skierowanie na skutki prawne}

Działanie człowieka jest celowe. Dokonujący czynności prawnej chce wywołać określone skutki prawne. Stąd działanie podmiotu zmierza zawsze do tego, by czynność była ważna ${ }^{24}$ i skuteczna z punktu widzenia prawnego oraz godziwa z punktu widzenia kanonicznego.

Jak widać, prawo kanoniczne wprowadza zatem dodatkową kategorię oceny skutków czynności prawnej - godziwość. Godziwość jest kategorią znaną tylko porządkowi kanonicznemu. Chodzi o dokonanie czynności prawnej z zachowaniem wszystkich przepisów prawa kanonicznego, które zawsze wiążą (w sumieniu), nawet jeśli nie pod rygorem nieważności. Złamanie tych przepisów oznacza,

${ }^{24}$ Nieważność jest stopniowalna także w prawie kanonicznym. Nieważność ta może być bowiem bezwzględna (nieważność prosta i kwalifikowana) albo względna (wzruszalność); może być sanowana (nieważność względna i prosta) bądź nie (nieważność kwalifikowana). W szczególności należy podkreślić możliwość tzw. actus non existens (np. „małżeństwo” między osobami tej samej płci, por. kan. 1055 § 1 CIC, 776 § 1 CCEO; przyjęcie świeceń przez kobietę, por. kan. 1024 CIC, 754 CCEO). Zob. Bressan 1970: 482-483; Baura 2002, 129-130. 
że czynność prawna została dokonana niegodziwie (illicite), ale ważnie (valide). Czynność prawna dokonana niegodziwie obciąża sumienie, a poza tym może wywołać środki dyscyplinarne w porządku kanonicznym (np. nałożenie pokuty przez właściwego przełożonego kościelnego).

\subsection{Zasady rządzące koncepcją kanoniczną czynności prawnej}

\subsubsection{Zasada personalizmu}

\subsubsection{Wymiary zasady personalizmu w koncepcji kanonicznej czynności prawnej}

Była już mowa o zasadzie personalizmu w całym porządku kanonicznym (zob. wyżej, pkt 1). Zasada personalizmu wyraża się chyba najpełniej w instytucji czynności prawnej. Można wyróżnić trzy wymiary zasady personalizmu w koncepcji kanonicznej czynności prawnej:

a) podkreślenie woli wewnętrznej osoby jako istoty czynności prawnej,

b) „personifikację" urzędu kościelnego,

c) osobisty charakter czynności prawnych w ramach sprawowanego urzędu kościelnego.

\subsubsection{Teoria woli (ad a)}

W koncepcji kanonicznej czynności prawnej chodzi - podobnie jak w prawie rzymskim (Litewski 1990, 160-161) - o wolę wewnętrzną (intentio interna) osoby, ukierunkowaną na określone skutki prawne (teoria woli). Prawo kanoniczne nie przyjęło teorii oświadczenia (declaratio externa) czy doniosłości prawnej (Geltungstheorie), obecnej w większości współczesnych ustawodawstw cywilnych (Michiels 1955, 593-594), w tym w prawie polskim (por. art. 60 k.c.) (Radwański 2008, 14-17). Jeżeli zatem dochodzi do niezgodności między wolą wewnętrzną (wewnętrznym przeżyciem) a jej zewnętrznym wyrazem (oświadczeniem woli), należy dać w prawie kanonicznym pierwszeństwo woli (teoria woli), a nie temu, jak ta wola byłaby zrozumiana przez roztropnego wiernego (teoria oświadczenia) (Radwański 1993, 140-141).

Przez przyjęcie teorii woli ustawodawca kościelny wskazał na prymat zasady personalizmu w porządku kanonicznym. Nie chodzi tylko o korzenie kanonistyki w prawie rzymskim (Ecclesia vivit lege Romana ${ }^{25}$ ). Odwoływanie się do aktu woli wewnętrznej jest oczywiste, jeśli weźmie się pod uwagę, że czynnościami prawnymi są również sprawowane w Kościele sakramenty - znaki łaski Bożej (Montan 2002, 43-64). Osobisty charakter relacji wiernego z Bogiem wymusza odniesienie się do rzeczywistej woli wewnętrznej wiernego.

\footnotetext{
${ }^{25}$ Paremia ta pochodzi z Lex Ribuaria (VIII w.), por. Dębiński 2007, 60-62.
} 
Najpełniej konsekwencje przyjęcia teorii woli w prawie kanonicznym widać przy okazji analizy zgody małżeńskiej w porównaniu z prawem świeckim. O ile prawo kanoniczne - w myśl zasady personalizmu - podkreśla rolę woli wewnętrznej (internus animi consensus), dopuszczając dowód nawet na symulację tejże zgody (jej sprzeczności z oświadczeniem woli - por. kan. $1101 \mathrm{CIC}$; 824 CCEO), o tyle prawo świeckie nie tylko, że takiej symulacji nie przyjmuje, stojąc na stanowisku teorii oświadczenia, ale nawet stanowi o oświadczeniu o wstąpieniu w związek małżeński (tak w polskim Kodeksie rodzinnym i opiekuńczym; por. art. $1 \S 1 ; 5 ; 6 \S 1 ; 7 \S 1-4 ; 9 \S 1 ; 15^{1} \S 1$ k.r.o.). Teoria oświadczenia nie pozwala systemom świeckim rozpoznać wyroków trybunałów kościelnych w sprawach małżeńskich (we Włoszech czy w Hiszpanii) z tytułu symulacji, gdyż prawo kanoniczne opiera się na teorii woli, a nie na - przyjętej w tamtych kodeksach cywilnych - teorii oświadczenia (Consorti 2014, 138-139). Porządek kanoniczny idzie w głąb i nie poprzestaje jedynie na oświadczeniu woli czy tylko na oświadczeniu o wstąpieniu w związek małżeński. Nie może zrobić inaczej, gdyż chodzi mu o rzeczywistą wolę osoby, o prawdę o sakramencie, o samą relację wiernego z Bogiem.

\subsubsection{Czynność kanonicznoprawna a urząd kościelny (ad b i c)}

Czynność kanonicznoprawna - o czym dalej (zob. pkt 3.3.2) - dotyczy również administracji (służby) Kościoła. Czynności kanonicznoprawnych dokonują też ci, którzy piastują urzędy kościelne (por. kan. 145 CIC; 936 CCEO). Dokonują tych czynności właśnie jako osoby. Powoduje to - inaczej niż w prawie świeckim - swoistą ,personifikację” urzędu kościelnego, a z drugiej strony - ,personalizację" aktu administracyjnego (Skonieczny 2014, 279) ${ }^{26}$.

Personifikacja jest konsekwencją dogmatu Wcielenia i oznacza ucieleśnienie władzy rządzenia w Kościele. Ta zaś nie istnieje w Kościele abstrakcyjnie, a tylko urzeczywistniając się poprzez urząd kościelny, który zawsze aktualizuje się i ukonkretnia w osobie, której został on powierzony. Dlatego czynność prawna (akt administracyjny) jest dokonywana nie tyle przez abstrakcyjnie pojęty organ administracyjny (np. biskupa diecezjalnego), ile przez konkretną osobę piastującą ten urząd kościelny (tj. ks. biskupa Jana Kowalskiego, biskupa diecezjalnego X) ${ }^{27}$.

Personifikacja w sposób konieczny musi oznaczać personalizację, czyli osobisty charakter czynności prawnych w ramach sprawowanego urzędu kościelnego. Urząd kościelny nie odrywa się bowiem od samej osoby, która go sprawuje. Jeżeli czynność prawna nie będzie czynnością ludzką, to będzie dotknięta tymi samymi

${ }^{26}$ Używając tego samego terminu, ale w innym kontekście, por. Sobański 1983, 77.

${ }^{27}$ Nieco inaczej zapatruje się na tę kwestię świeckie prawo administracyjne, w którym decyzję administracyjną zawsze wydaje organ administracyjny, np. Prezydent Miasta Krakowa. Konsekwencją personifikacji jest wygaśnięcie zadań związnych z urzędem z chwilą jego wakatu, np. śmiercią papieża (por. n. 14, 24-26 Konstytycji apostolskiej Universi dominici gregis o wakacie Stolicy Apostolskiej, zob. Ioannes Paulus PP. II 1996). 
wadami, jak inne czynności prawne w porządku kanonicznym (por. kan. 124-127 CIC; 931-934 CCEO). Skutkiem takiego ujęcia (personalizacji) aktu administracyjnego w prawie kanonicznym jest brak autonomicznej instytucji nieważności aktu administracyjnego na wzór polskiego prawa administracyjnego (art. 156 k.p.a.). Nieważność kościelnego aktu administracyjnego jest tożsama z nieważnością czynności prawnej w prawie kanonicznym (zob. Skonieczny 2012: 19).

Innym aspektem zasady personalizacji aktów administracyjnych w porządku kanonicznym jest ich charakter osobisty. Decyzję podejmuje (czynności prawnej dokonuje) tylko jedna osoba - przełożony kościelny. Ustawodawca kościelny chce, by to przełożony kościelny ponosił odpowiedzialność - przede wszystkim moralnie, ale i prawnie - za daną decyzję i by była jasność w przedmiocie tejże odpowiedzialności. To założenie skutkuje wyraźnym odgraniczeniem kompetencji między przełożonym a radami czy innymi gremiami lub osobami, które mu pomagają w służbie dla wspólnoty kościelnej (por. kan. 127 CIC; 934 CCEO).

\subsubsection{Zasada uniwersalizmu}

Prawo kanoniczne stanowi w miarę jednolity system prawny. Nie odróżnia więc prawa cywilnego od prawa administracyjnego, prawa prywatnego od publicznego. Wszystkie normy prawa kanonicznego mają bowiem charakter publicznoprawny ${ }^{28}$.

Ponadto w Kościele jest tylko jedna władza (por. kan. 129 § 1 CIC; $979 \S 1$ CCEO $)^{29}$. Oznacza to, że porządek kanoniczny nie przyjął Monteskiuszowskiej zasady trójpodziału władz, pozostając przy zasadzie jedności władzy, choć wyróżnia funkcję ustawodawczą, wykonawczą i sądowniczą we władzy rządzenia (por. kan. 135 § 1 CIC; $985 \S 1$ CCEO).

Ta jednolitość porządku kanonicznego oraz zasada jedności władzy kościelnej musiały wpłynąć na szeroki zakres przedmiotowy instytucji czynności kanonicznoprawnej. Pod tym kątem prawo kanoniczne jest wyjątkowe i z pewnością koncepcja kanoniczna czynności prawnej różni się od tej, która występuje w polskim prawie cywilnym. Czynność prawna w porządku kanonicznym obejmuje nie tylko czynność cywilnoprawną (jak w prawie polskim, np. zawarcie małżeństwa kanonicznego), ale i czynności administracyjnoprawne (np. wydanie dekretu, czyli aktu administracyjnego) czy nawet czynności publicznoprawne w postaci wydania ustawy czy wyroku ${ }^{30}$. To dlatego ustawodawca kościelny zdecydował się na termin actus iuridicus, a nie negotium iuridicum.

${ }^{28}$ Podobnie por. Fedele 1973, 126-155, a zwłaszcza 132; Sobański 1983, 116-117; Skonieczny 2010,66 .

${ }^{29}$ Por. Skonieczny 2012, 17-18. Zasadę jednej władzy kościelnej (potestas sacra) najlepiej opisał w kanonistyce ks. prof. Klaus Mörsdorf (1909-1989), założyciel szkoły monachijskiej. Przedstawienie tej teorii w literaturze polskiej zob. Skonieczny 2013: 17-38.

${ }^{30}$ Por. Romani 1938, 103-104; Michiels 1955, 574-575. W nowszej literaturze zob. Fornés 1985, 88; Maternini Zotta 2002, 103-104. Przykładowo, jeżeli biskup diecezjalny wydał ustawę 
Termin ten bowiem może być zastosowany do wszystkich czynności, także o charakterze „publicznoprawnym”, dokonywanych w porządku kanonicznym (por. Robleda 1962, 414-418; Thériault 2004, 796).

Jak widać, pojęcie czynności prawnej w porządku kanonicznym jest bardzo szerokie i obejmuje jakąkolwiek działalność osoby na gruncie tego prawa. Jest to wynik zasady personalizmu z prawie kanonicznym. Dzieła człowieka - ustawy, akty administracyjne, wyroki, sakramenty - nigdy nie mogą się od niego oderwać. Są to dzieła osoby właśnie, a nie jakiegoś, abstrakcyjnie ujętego, organu władzy ustawodawczej czy publicznej. Stąd szeroki zakres pojęcia czynności prawnej (jako wytworu osoby) w prawie kanonicznym.

\subsubsection{Zasada trwałości, czyli zachowania czynności prawnej}

Człowiek chce osiągnąć cele, które sobie stawia, także poprzez dokonywanie czynności prawnych. Najwyższym celem człowieka jest zbawienie (por. kan. 1752 CIC). Zasada personalizmu w instytycji czynności kanonicznoprawnej oznacza więc takie działanie ustawodawcy kościelnego, aby cele czynności kanonicznoprawnych zostały osiągnięte. Zasada trwałości czynności prawnej jest zatem pochodną zasady personalizmu (zob. Maternini Zotta 2002, 118).

Zasada trwałości czynności prawnej w porządku kanonicznym oznacza nie tylko domniemanie (wzruszalne) ważności tejże czynności, jeżeli została ona dokonana zgodnie z wymogami zewnętrznymi prawa (rite - $124 \S 2$ CIC, ad normam iuris - kan. $931 \S 2$ CCEO), lecz także zasadę tę należy widzieć w tych wszystkich instytucjach kanonicznych, które umożliwiają sanowanie (,uzdrawianie") nieważnej czynności prawnej (por. Maternini Zotta 2002, 118-119). Taka sanacja zaś jest o wiele częściej możliwa, również w praktyce, w prawie kanonicznym niż w systemach prawa świeckiego. Chodzi przecież o najważniejszy cel prawa kanonicznego - zbawienie dusz.

\section{PODSUMOWANIE}

Kanoniczna koncepcja czynności prawnej wyrasta ze wspólnej tradycji prawnej Europy, ale jej fundamentem jest ponadto chrześcijańska wizja człowieka jako osoby. To właśnie dominacja tej antropologii wpłynęła na szereg rozwiązań szczegółowych komentowanej instytucji kanonicznoprawnej, zwłaszcza pozostanie przy teorii woli (zasada personalizmu). Z kolei założenia konstytucyjne Kościoła (zasada jedności władzy) doprowadziły do rozszerzenia pojęcia czynności prawnej na jakąkolwiek czynność w porządku kanonicznym, także o charakterze publicznym (jak np. wydanie ustawy czy aktu administracyjnego). Kanoniczna

kościelną, cierpiąc na chorobę psychiczną, to nie jest to prawdziwa ustawa, skoro nie jest to actus humanus, a zatem i prawdziwa czynność prawna. 
koncepcja czynności prawnej jest zatem ciekawym przykładem wpływu założeń teologicznych i filozoficznych na kształt instytucji prawnej. Ta instytucja zaś ma służyć celowi najwyższemu - zbawieniu dusz (por. kan. 1752 CIC).

\section{BIBLIOGRAFIA}

\section{Źródla}

\section{A. Źródla prawa kanonicznego}

„Codex Canonum Ecclesiarum Orientalium auctoritate Ioannis Pauli PP. II promulgatus”. 1990. Acta Apostolicae Sedis 82: 1045-1364. Przekł. polski: Kodeks Kanonów Kościołów Wschodnich. 2002. Tł. Leszek Adamowicz, Marzena Dyjakowska. Lublin: Wydawnictwo Archidiecezji Lubelskiej „Gaudium”.

„Codex Iuris Canonici auctoritate Ioannis Pauli PP. II promulgatus”. 1984. Acta Apostolicae Sedis 75 (1983/II): III-XXX; 1-317. Przekł. polski: Kodeks Prawa Kanonicznego, zatwierdzony przez Konferencję Episkopatu. Poznań: Pallottinum.

„Codex Iuris Canonici Pii X P.M. iussu digestus, Benedicti P. XV auctoritate promulgatus”. 1917. Acta Apostolicae Sedis 9 (II): 1-521.

Ioannes Paulus PP. II. 1996. „Constitutio apostolica Universi dominici gregis de Sede Apostolica vacante deque Romani Pontificis electione”. Acta Apostolicae Sedis 88: 305-343. Przekł. polski: Codex Iuris Canonici. Kodeks Prawa Kanonicznego. Komentarz. 2011. Red. Piotr Majer. 1333-1379. Kraków: Wolters Kluwer Polska.

Pismo Święte Starego i Nowego Testamentu w przekładzie z języków oryginalnych. 1980. Red. naukowa Augustyn Jankowski, Lech Stachowiak, Kazimierz Romaniuk. Poznań: Pallottinum.

Sacrosanctum Concilium Oecumenicum Vaticanum II. 1966. „Constitutio pastoralis Gaudium et spes de Ecclesia in mundo huius temporis”. Acta Apostolicae Sedis 58: 1025-1115. Tekst polski: Sobór Watykański II. Konstytucje, dekrety, deklaracje. Tekst polski. 1967. Red. Julian Groblicki, Eugeniusz Florkowski, Karol Wojtyła. 533-657. Paris: Éditions du Dialogue.

\section{B. Źródła prawa świeckiego}

„Digesta”. 1872. W Corpus Iuris Civilis. Vol. 1. Red. Theodorus Mommsen, Paulus Krueger. Berolini: Weidmannos.

Ustawa z dnia 14 czerwca 1960 r. - Kodeks postępowania administracyjnego (t.j. Dz. U. 2016, poz. 23).

Ustawa z dnia 25 lutego 1964 r. - Kodeks rodzinny i opiekuńczy (t.j. Dz. U. 2015, poz. 583).

Ustawa z dnia 23 kwietnia 1964 r. - Kodeks cywilny (t.j. Dz. U. 2016, poz. 380 ze zm.).

\section{Literatura}

Aymans, Winfried, Klaus Mörsdorf. 1991. Kanonisches Recht. Lehrbuch aufgrund des Codex Iuris Canonici. T. 1: Einleitende Grundfragen und Allgemeine Normen. Paderborn: Ferdinand Schöningh.

Baura, Eduardo. 2002. „Il sistema delle invalidità (inesistenza e nullità, annullabilità e rescindibilità) dell'atto giuridico". W L'atto giuridico nel diritto canonico. 121-141. Città del Vaticano: Libreria Editrice Vaticana.

Baura, Eduardo. 2013. Parte generale del diritto canonico. Diritto e sistema normativo. Roma: EDUSC.

Bressan, Aloysus. 1970. „De inexsistentia et nullitate actus iuridici in CIC”. Periodica de re morali canonica liturgica 59: 471-483. 
Chiappetta, Luigi. 2011. Il Codice di Diritto Canonico. Commento giuridico-pastorale. Red. Francesco Catozzella, Arianna Catta, Claudia Izzi, Luigi Sabbarese. T. 1. Bologna: Edizione Dehoniane Bologna.

Codex Iuris Canonici. Kodeks Prawa Kanonicznego. Komentarz. 2011. Red. Piotr Majer. Kraków: Wolters Kluwer Polska.

Consorti, Pierluigi. 2014. Diritto e religione. Roma: Editori Laterza.

Cortés Diéguez, Myriam. 2014. „De los actos jurídicos”. W Código de Derecho Canónico. Edición bilingüe comentada. Colab. Federico Aznar Gil, Myriam Cortés Diéguez, José María Díaz Moreno, Luis A. García Matamoro, José San José Prisco. 91-96. Madrid: Biblioteca de Autores Cristianos.

De Paolis, Valesio. 1995. „Il Libro Primo del Codice: Norme Generali (cann. 1-203)”. W Il diritto nel mistero della Chiesa. Red. Gruppo Italiano Docenti di Diritto Canonico. T. 1. 235-497. Roma: Pontificia Università Lateranense.

De Paolis, Valesio. 2002. „L'atto giuridico”. W L'atto giuridico nel diritto canonico. 23-41. Città del Vaticano: Libreria Editrice Vaticana.

De Paolis, Valesio, Andrea D’Auria. 2008. Le Norme Generali. Commento al Codice di Diritto Canonico. Libro Primo. Città del Vaticano: Urbaniana University Press.

Dębiński, Antoni. 2007. Kościót i prawo rzymskie. Lublin: Wydawnictwo Katolickiego Uniwersytetu Lubelskiego.

Di Carlo, Simonetta. 2002. „L'atto giuridico nel Codex Iuris Canonici del 1917 e del 1983: normative a confronto". W L'atto giuridico nel diritto canonico. 7-22. Città del Vaticano: Libreria Editrice Vaticana.

Dzierżon, Ginter. 2000. „Aplikacja kategorii aktu prawnego w kanonicznym prawie małżeńskim”. Ius Matrimoniale 5 (11): 9-21.

Dzierżon, Ginter. 2002. Niezdolność do zawarcia matżeństwa jako kategoria kanoniczna. Warszawa: Wydawnictwo Uniwersytetu Kardynała Stefana Wyszyńskiego.

Fedele, Pio. 1973. Discorsi sul Diritto Canonico. Roma: Officium Libri Catholici.

Fornés, Juan. 1985. „El acto jurídico-canónico (Sugerencias para una teoría general)”. Ius Canonicum 25: 57-89.

Gangoiti, Benito. 1993. „De los actos juridicos”. W Código de Derecho Canónico. Edición bilingüe, fuentes y comentarios de todos los cánones. Red. Antonio Benlloch Poveda. 79-83. Valencia: EDICEP.

García Martín, Julio. 2015. Le norme generali del Codex Iuris Canonici. Venezia: Marcianum Press. Hervada, Javier. 1989. Diritto costituzionale canonico. Milano: Giufrè Editore.

Hughes, Michael. 1980. „A New Title in the Code: On Juridical Acts”. Studia Canonica 14: 396-401. L'atto giuridico nel diritto canonico. 2002. Città del Vaticano: Libreria Editrice Vaticana.

Litewski, Wiesław. 1990. Rzymskie prawo prywatne. Warszawa: PWN.

Lombardía, Pedro. 1985. Lezioni di Diritto Canonico. Instroduzione-Diritto Costituzionale - Parte Generale. Red. Gaetano Lo Castro. Milano: Giufrè Editore.

Maternini Zotta, Maria Fausta. 2002. „Il principio di conservazione dell'atto giuridico”. W L'atto giuridico nel diritto canonico. 103-119. Città del Vaticano: Libreria Editrice Vaticana.

Michiels, Gommarus. 1955. Principia generalia de personis in Ecclesia. Commentarius Libri II Codicis Juris Canonici. Canones praeliminares 87-106. Paris: Desclée et Socii.

Molano, Eduardo. 2011. „Czynności prawne”. W Codex Iuris Canonici. Kodeks Prawa Kanonicznego. Komentarz. Red. Piotr Majer. 146-150. Kraków: Wolters Kluwer Polska.

Montan, Agostino. 2002. „Gli sacramenti come atti giuridici”. W L'atto giuridico nel diritto canonico. 43-64. Città del Vaticano: Libreria Editrice Vaticana.

Pawluk, Tadeusz. 1990. Prawo kanoniczne wedtug Kodeksu Jana Pawła II. T. 1: Zagadnienia wstęne i normy ogólne. Olsztyn: Warmińskie Wydawnictwo Diecezjalne. 
Peters, Eduardus N. 2005. Incrementa in progressu 1983 Codicis Iuris Canonici. Montréal: Wilson \& Lafleur.

Petrizzelli, Sandro. 2006. L'atto giuridico con speciale riferimento al contratto matrimoniale (cann. 124 e 1057). Roma: Pontificia Universitas Gregoriana.

Pinto, Pio Vito. 2001. „Libro I. Norme Generali”. W Commento al Codice di Diritto Canonico. Red. Pio Vito Pinto. 1-109. Città del Vaticano: Libreria Editrice Vaticana.

Pree, Helmuth. 1998. „Rechtsakt: Allgemeine Grundlegung”. W Münsterischer Kommentar zum Codex Iuris Canonici. Red. Klaus Lüdicke. T. 1. Essen: Ludgerus Verlag.

Radwański, Zbigniew. 1993. Prawo cywilne - część ogólna. Warszawa: C.H. Beck-PWN.

Radwański, Zbigniew. 2008. „Zagadnienia ogólne czynności prawnych”. W System Prawa Prywatnego. T. 2: Prawo cywilne - część ogólna. Red. Zbigniew Radwański. 2-38. Warszawa: C.H. Beck.

Robleda, Olisius. 1962. „De conceptu actus iuridici. Excursus theoricus”. Periodica de re morali, canonica, liturgica 51: 413-446.

Robleda, Olís. 1964. La nulidad del Acto Jurídico. Roma: Libreria Editrice dell’Università Gregoriana.

Romani, Silvio. 1938-1939. „De factis actibus negotiisque juridicis”. Ius Pontificium 18: 101-104, 192-197; 19: 48-54.

Skonieczny, Piotr. 2010. La buona fama: problematiche inerenti alla sua protezione in base al can. 220 del Codice di Diritto Canonico latino. Romae: Angelicum University Press.

Skonieczny, Piotr. 2012. „Kościelny akt administracyjny według Kodeksu Prawa Kanonicznego z 1983 r. Wprowadzenie dla prawników świeckich”. Casus 66: 17-24. http://www.kolegium. krakow.pl/_files/Casus_nr_66.pdf [dostęp: 7.07.2016].

Skonieczny, Piotr. 2013. „Potestas sacra według Klausa Mörsdorfa - założenia teologiczne, struktura, sposób przekazywania i charakter". Annales Canonici 9: 17-38.

Skonieczny, Piotr. 2014. „Umowa powierzenia parafii instytutowi zakonnemu: uwagi ogólne”. Poznańskie Studia Teologiczne 28: 269-304.

Sobański, Remigiusz. 1979. Kościót - prawo-zbawienie. Katowice: Księgarnia św. Jacka.

Sobański, Remigiusz. 1983. Kościót jako podmiot prawa. Elementy eklezjologii prawnej. Warszawa: Akademia Teologii Katolickiej.

Sobański, Remigiusz. 1992. Teoria prawa kościelnego. Warszawa: Akademia Teologii Katolickiej.

Sobański, Remigiusz. 2001. Nauki podstawowe prawa kanonicznego. T. 1. Teoria prawa kanonicznego. Warszawa: Wydawnictwo Uniwersytetu Kardynała Stefana Wyszyńskiego.

Sobański, Remigiusz. 2003. „Czynności prawne”. W Józef Krukowski, Remigiusz Sobański, Komentarz do Kodeksu Prawa Kanonicznego. T. 1: Księga I. Normy ogólne. Red. Józef Krukowski. 201-212. Poznań: Pallottinum.

Thériault, Michel. 2004. „Juridical Acts”. W Exegetical Commentary on the Code of Canon Law: prepared under the responsability of the Martin de Azpilcueta Institute Faculty of Canon Law University of Navarre. T. 1. Red. Ángel Marzoa, Jorge Miras, Rafael Rodríguez-Ocaña. Przekł. Ernest Caparros. 796-814. Montreal: Wilson \& Lafleur.

Thomas Aquinas, St. 1888. Summa Theologica. Romae: S.C. de Propaganda Fide. http://www.corpusthomisticum.org/iopera.html [dostęp: 7.07.2016].

Urrutia, Francisco Javier. 1994. Les normes générales. Commentaire des canons 1-203. Paris: Editions Tardy.

Vela Sanchez, Luis. 1993. „Atto giuridico (Actus iuridicus)”. W Nuovo Dizionario di Diritto Canonico. Red. Carlos Corral Salvador, Valesio De Paolis, Gianfranco Ghirlanda. 66-70. Cinisello Balsamo: Edizioni San Paolo.

Wijlens, Myriam. 2000. „Juridic Acts”. W: New Commentary on the Code of Canon Law. Red. John P. Beal, James A. Coriden, Thomas J. Green. 177-183. New York: Paulist Press. 
Windscheid, Bernhard. 1879. Lehrbuch des Pandektenrechts. T. 1. Stuttgart: Verlag von Ebner \& Seubert. http://dlib-pr.mpier.mpg.de/m/kleioc/0010/exec/bigpage/\%22243107_00000001.gif\%22 [dostęp: 6.07.2016].

Wojtyła, Karol. 1969. Osoba i czyn. Kraków: Polskie Towarzystwo Teologiczne.

Zieliński, Maciej. 2002. Wykładnia prawa. Zasady, reguły, wskazówki. Warszawa: Wydawnictwo Prawnicze LexisNexis.

Ziembiński, Zygmunt. 1992a. „Normy postępowania”. W Andrzej Redelbach, Sławomira Wronkowska, Zygmunt Ziembiński. Zarys teorii państwa i prawa. 73-93. Warszawa: Wydawnictwo Naukowe PWN.

Ziembiński, Zygmunt. 1992b. „Wykładnia prawa i wnioskowanie prawnicze”. W Andrzej Redelbach, Sławomira Wronkowska, Zygmunt Ziembiński. Zarys teorii państwa i prawa. 186-217. Warszawa: Wydawnictwo Naukowe PWN.

fr. Piotr Skonieczny OP

\title{
THE CANONICAL CONCEPT OF THE JURIDICAL ACT AN INTRODUCTION FOR CIVIL LAWYERS
}

\begin{abstract}
The author gives a general presentation of the canonical concept of the juridical act (cf. canons 124-127 CIC). He indicates its theological and anthropological basis (the person and the actus humanus) as well as its sources in the European juridical tradition. According to the author, in the canonical system the juridical act is a human act (actus humanus) that is a conventional act (a formal act), and it results in certain specific and desired legal effects. The canonical concept of the juridical act is regulated by three rules: the rule of personalism (the emphasis on its personal character), the rule of universality (the extented scope of the application of this term also to public acts), and the rule of permanence (the continuance of the juridical act).
\end{abstract}

Keywords: juridical act, canon law, canons 124-127 CIC, canons 931-934 CCEO. 